\title{
Determination of Risk to Groundwater Aquifers from Crude Oil Pipelines
}

\author{
Huseyin Murat Cekirge \\ Department of Mechanical Engineering, the Grove School of Engineering, the City College of the City University of New York, New York, \\ USA
}

\section{Email address:}

hmcekirge@usa.net

\section{To cite this article:}

Huseyin Murat Cekirge. Determination of Risk to Groundwater Aquifers from Crude Oil Pipelines. International Journal of Environmental Monitoring and Analysis. Special Issue: Environmental Social Impact Assessment (ESIA) and Risk Assessment of Crude Oil and Gas Pipelines.Vol. 3, No. 6-1, 2015, pp. 39-46. doi: 10.11648/j.ijema.s.2015030601.15

\begin{abstract}
The pipelines are passing over groundwater aquifers and any oil spills from the pipeline is major threat to the aquifers. The methodology to determine this risk will be introduced; the detailed analysis will be explained and an example is presented. The software used in the calculation is also explained.
\end{abstract}

Keywords: Crude Oil Pipeline's Risk to Groundwater, Zone of Contribution, Capture Zones, Risk Criteria for Groundwater from Crude Oil Pipelines

\section{Introduction}

Required elements of the study include data collection of well sites and each aquifer, and use of a computer-based groundwater flow model to determine 50-day and 400-day capture zones and the Zone of Contribution (ZOC), [1 - 11]. The analyses are required to be updated for every kilometer of pipeline (KP, kilometer point) crossing the aquifer as necessary; and also to reflect the results obtained. The methodology must be developed across the entire pipeline to provide guidance for environmental protection. Lastly, oil spill response procedures will be developed based on the knowledge gained during this process.

During this analysis, a steady state geohydrology computer program called Wellhead Analytical Element Model (WhAEM) 2000 or WhAEM, [2], developed by the United States Environmental Protection Agency, is used in the evaluations. Well data will be extensively updated with a database, map information, reports and well logs. Model runs were made to determine the 50-day, 400-day and 4000-day capture zones of wells in each aquifer along the pipeline. The wells in the sample aquifer are used only for seasonal irrigation, so the model run was made for 300-days which represent the maximum number of operational days within a 400-day period. This risk assessment procedure, the Groundwater occurrence-Overall lithology-Depth to groundwater (GOD) method is described in the World Bank website publication; Assessment of Groundwater Pollution
Risk; Morris and Foster, [4].

Taking the 'conservative' approach, the Quantified Risk Assessment (QRA) risk criteria were used to develop groundwater risk values for every kilometer; KP, of pipeline crossing each aquifer. Data from this study are incorporated into the Project's Geographic Information System (GIS) to provide pipeline route, well location, capture zone and ZOC overlays to 1:25.000-scale topographic maps. The maps of 50-day, 300-day, 400-day and 4000-day capture zones and results of ZOC interception of the pipeline are included as example maps of this report. A spill response procedure is developed for all groundwater operational zones. The overarching response strategy is to prevent spilled oil from entering the aquifer. The procedure continues until the threat to the aquifer is removed, and refers to information regarding site geology and aquifer characteristics included in this report.

This analysis is undertaken to fulfill the requirements of the Environmental Management and Monitoring Plans defined in the Project's ESIA in general. The development of the Groundwater Protection Strategy requires a systematic technical approach to the definition of groundwater sensitivity. These results will be used in the oil spill response planning.

The following technical approach provides a summary of the core steps to be taken in realization of the groundwater protection strategy:

Step 1. The major individual well field production zones 
within the groundwater operational zones will be assessed in terms of their proximity and likely connectivity to the pipeline. Production zones within close proximity and / or in hydraulic connection with the pipeline will be selected for review and a groundwater database will be updated.

Step 2. Based on the information provided in the literature reviews, the aquifer sensitivity will be assessed. This is likely to be guided by the importance and quality of the resource. Numerical risk values will be derived for the aquifer protection zones defined under Step 3.

Step 3. Based on the complexity of the flow field, a suitable analytical or semi-analytical model will be chosen to delineate the 50 and 400-day capture zones and the Zone of Contribution (ZOC). USEPA Wellhead Protection Zone methodology can be used to delineate the protection zones, Figure 1.

Step 4. The flow field and capture zones results will then be digitized and geo-referenced in the GIS database. The GIS will then be used to compute the level of sensitivity for each one kilometer section of pipeline. The results will be used to update the existing pipeline ERA (Environmental Risk Analysis) and will provide valuable information with regard to Oil Spill Response Planning; the procedures used in this evaluation are summarized in Figure 2.

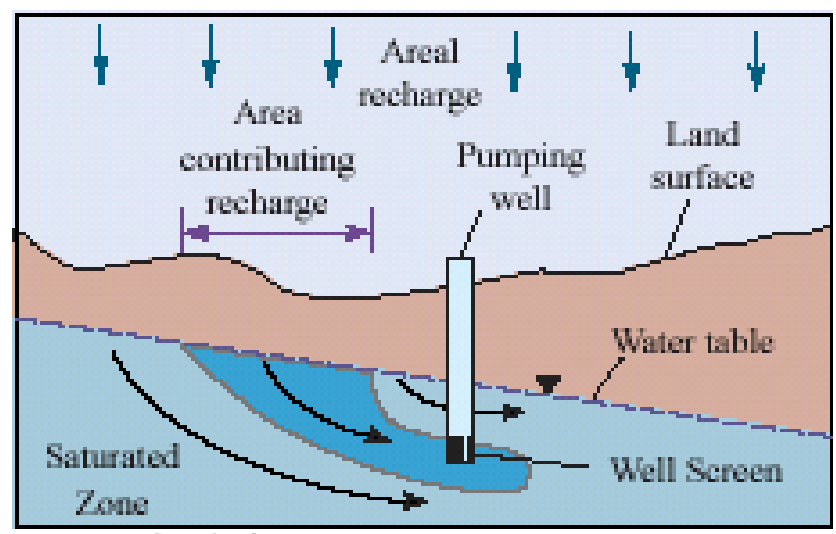

Cross-Soctional View

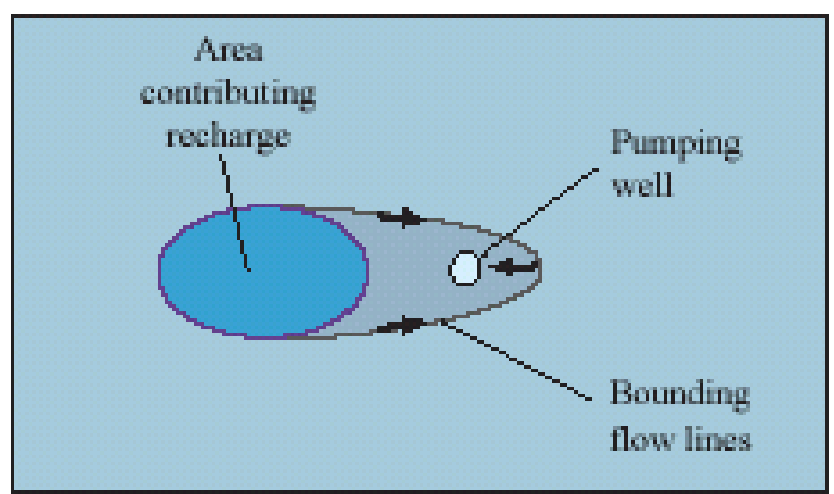

Map View (Saturated Zone)

Figure 1. Illustration of the zone of contribution; 'Area of Contributing Recharge'; can be disconnected to the well site, [6] and [7].

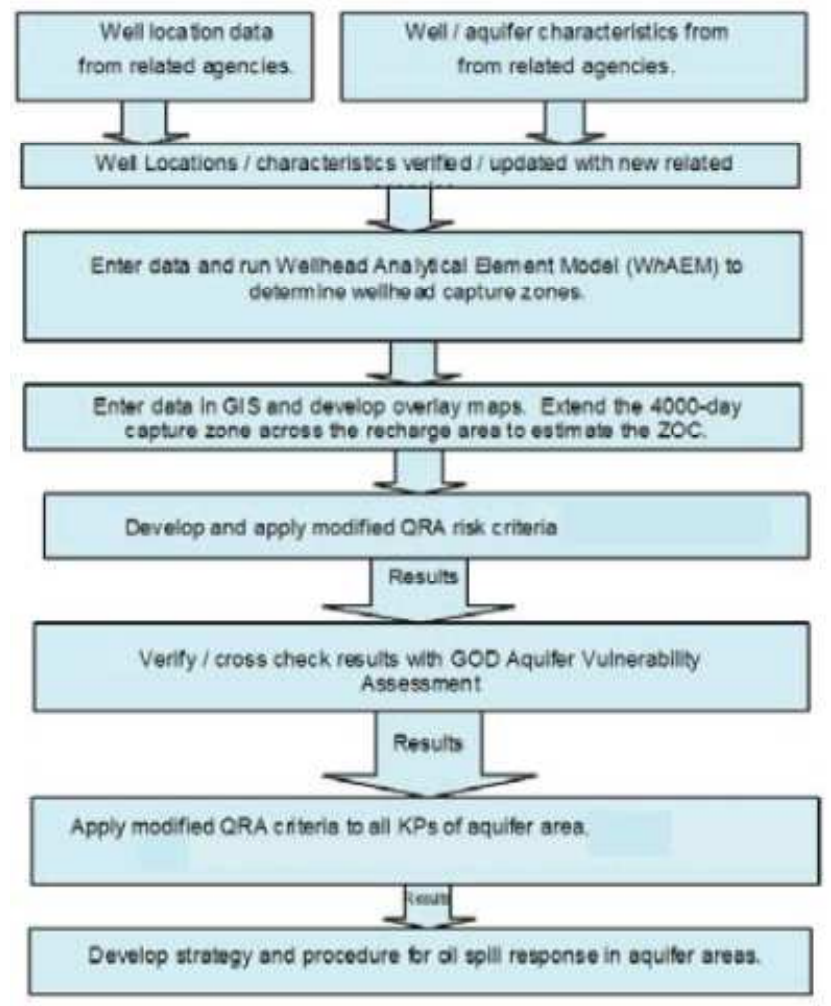

Figure 2. Procedures used in this paper.

\section{Analysis}

\subsection{Preparation of the Model}

The WhAEM model requires a digital map base with coordinates. This was prepared in AutoCAD using the project's pipeline route in UTM coordinates. Lines of equal hydrological potential were derived from previous reports and public records on each aquifer and added to the file. The map was exported from AutoCAD and imported directly into WhAEM in the base map were then traced and given the appropriate characteristic.

The WhAEM model utilizes a series of entry screens to set model parameters for each model run. The necessary data:

- Aquifer Properties;

- Settings for Contouring;

- Settings for Tracing; and

- Well Properties.

Well location data were input into a Geographic Information System (GIS). WhAEM model results having an interception of the pipeline with a capture zone or ZOC were input into the GIS by geo-rectifying the output image of the WhAEM model. All capture zone were traced into a GIS layer as a polygon for additional risk analysis and for incorporation into the Project's GIS.

\subsection{Determining the Zone of Contribution (ZOC)}

The Zone of Contribution (ZOC) around a well is a surface representation of the area that contributes water to the well, and infers that any contamination within the zone of 
contribution would eventually reach the well.

The ZOC is influenced by the three dimensional structure of the aquifer, in particular, by areas where there is confined or artesian flow and by areas of defined recharge. In other words, the ZOC will not be present if there is no connection to surface input or recharge. Therefore, the Zone of Contribution was determined as follows:

1. WhAEM was run for 4,000-days to indicate the capture zone for this time period. WhAEM is a steady state model so this indicates the general source of water for the well site but does not reflect the three-dimensionality of the aquifer, and, in particular, surface recharge areas;

2. Recharge areas for each aquifer were entered into the Geographic Information System (GIS);

3. The GIS was used to overlay and intersect the 4000-day ZOC with the aquifer's recharge area;

4. Maps were created where the plume has the potential of extending further into the recharge area; this was estimated by visually extending the 4000 -day plume. The sensitivity analysis in next section indicates that longer capture duration primarily alters the length of the capture zone, but has little change on its width. So the ZOC is estimated by extending the length of the 4000-day capture zone across the entire recharge area, but only slightly increasing its width as it is extended. The extension of the 4000-day aquifer (essentially the $>4000$-day capture zone) across the recharge area was mapped as a separate GIS layer; and

5. Maps of each aquifer were produced to indicate the ZOC based on the overlay of the 4000-day and the extended 4000-day capture zones.

\subsection{Sensitivity Analysis}

WhAEM generalizes several aquifer characteristics that influence the transport of water through the aquifer. The assumptions are:

- Assumption of single uniform flow: The model assumes that there is no multi-layer flow. For instance, if wells are obtaining water from distinctly screened zones along the well pipe. All water is obtained across the length of a screened pipe indicating that a single uniform flow is a valid approximation.

- Assumption of a homogeneous aquifer: The WhAEM model considers that small inclusions of clay or gravel are inconsequential except if their size is on the order of the capture zone width or larger. This is not the case for the aquifers analyzed. The $50-100 \mathrm{~m}$ of screened water pipe crosses many smaller layers of various sediment types. Water is gathered across these layers in each well.

- Assumption of non-stratified aquifer: An aquifer having significantly different hydraulic conductivities for different parts of the aquifer along a single pipe length will yield different capture times. This information is not available for this study, but since a single hydraulic conductivity is determined for each well, based on the transmissibility for the entire well sequence and the thickness of the aquifer (crossing many possible aquifer lenses), the assumption of non-stratification is supported.

- Assumption of non-transient (constant) flow rates: Summer pumping, as in agricultural areas, differs from winter pumping. For this study, the pumping rate is assumed to be constant year round. This results in a 'conservative' approach where the capture zone is maximized.

To test the potential impact of changing WhAEM model entry parameters, an analysis was performed to determine the sensitivity of each value. The changes selected for analysis reflect large; $100 \%$ or more; to the base configuration values to ensure that changes can be visually observed. Lesser, more realistic changes in values, e.g. 10-20\%, would therefore produce relatively smaller alteration of the capture zone.

\subsection{Environmental Risk Analysis}

This section first develops groundwater risk criteria and then applies the criteria to evaluate groundwater risk for each kilometer of pipeline passing through every aquifer. As appropriate, the existing Quantified Risk Assessment (QRA), which was made at the initial stage of the planning, is updated to reflect the knowledge gained during the analysis of each groundwater operational zone. The QRA was performed across the entire pipeline to provide guidance for environmental protection. In the case of groundwater, the QRA delineated the boundaries of each of the major aquifers to then provide a higher level of protection than in non-aquifer areas. The purpose of formulating this risk analysis is to determine if there are exceedences to the QRA values due to capture zones that intersect the pipeline and to provide further information to the Emergency Response Team in the event of an oil spill.

\subsubsection{Risk Criteria}

There are several methods to determine the potential risk of aquifer contamination. The paper utilizes two evaluation procedures to each aquifer. These are:

- The Quantified Risk Assessment (QRA), [1] and

- The Groundwater occurrence-Overall lithology-Depth to groundwater (GOD) process, described in [4].

\subsubsection{QRA Risk Criteria}

Groundwater risk in the QRA report is based on potential pollution contact and the receptor that is in jeopardy of contact In Table 1, this report presents the QRA criteria by including information about the capture zone and well site characteristics from this report. To determine the groundwater risk value for each pipeline kilometer, the Receptor and Contact values from Table 1 are cross-referenced using the matrix in Table 2. 
Table 1. Criteria to determine valuation of risk to groundwater resources, quantified risk assessment (QRA), [1].

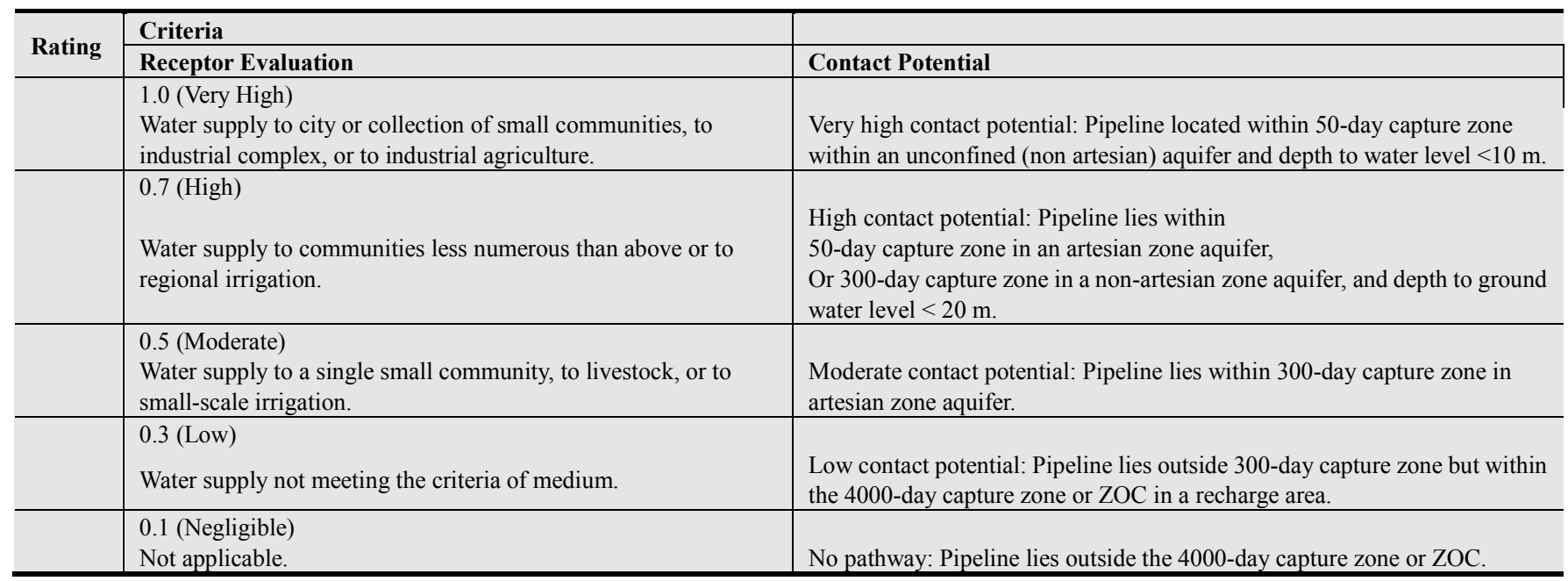

\begin{tabular}{|c|c|c|c|c|c|c|}
\hline \multicolumn{7}{|c|}{ Receptor Value } \\
\cline { 2 - 7 } & & 1.00 & 0.70 & 0.50 & 0.30 & 0.10 \\
\cline { 2 - 7 } $\begin{array}{r}\text { Contact } \\
\text { Potential }\end{array}$ & 1.00 & 1.00 & $\mathbf{0 . 7 0}$ & $\mathbf{0 . 5 0}$ & $\mathbf{0 . 3 0}$ & $\mathbf{0 . 1 0}$ \\
\cline { 2 - 7 } & 0.70 & $\mathbf{0 . 7 0}$ & $\mathbf{0 . 7 0}$ & $\mathbf{0 . 5 0}$ & $\mathbf{0 . 3 0}$ & $\mathbf{0 . 1 0}$ \\
\cline { 2 - 7 } & 0.50 & $\mathbf{0 . 5 0}$ & $\mathbf{0 . 5 0}$ & $\mathbf{0 . 5 0}$ & $\mathbf{0 . 3 0}$ & $\mathbf{0 . 1 0}$ \\
\cline { 2 - 7 } & 0.30 & $\mathbf{0 . 3 0}$ & $\mathbf{0 . 3 0}$ & $\mathbf{0 . 3 0}$ & $\mathbf{0 . 3 0}$ & $\mathbf{0 . 1 0}$ \\
\hline & 0.10 & $\mathbf{0 . 1 0}$ & $\mathbf{0 . 1 0}$ & $\mathbf{0 . 1 0}$ & $\mathbf{0 . 1 0}$ & $\mathbf{0 . 1 0}$ \\
\hline
\end{tabular}

Table 2. Matrix to determine potential risks to groundwater resources along the pipeline based on criteria from Table 1, $1.0=$ very high, 0.7=high, $0.5=$ moderate, $0.3=$ low, $0.1=$ negligible.

\subsubsection{GOD Risk Criteria}

The GOD (Groundwater occurrence-Overall

lithology-Depth to groundwater) [4] methodology defines five classes of potential vulnerability to aquifer pollution Table 3 . To derive the vulnerability to aquifer, the process uses the type of groundwater occurrence, lithology of the aquifer, and the depth to groundwater, as laid out in [4].

Table 3. Practical significance of relative classes of aquifer pollution vulnerability, [4].

\begin{tabular}{l|l}
\hline Vulnerability Class & Definition \\
\hline Extreme & $\begin{array}{l}\text { Vulnerable to most water pollutants with relatively } \\
\text { rapid impact in many pollution scenarios. }\end{array}$ \\
\hline High & $\begin{array}{l}\text { Vulnerable to many pollutants, except those highly } \\
\text { adsorbed or readily transformed, in many pollution } \\
\text { scenarios. }\end{array}$ \\
\hline Moderate & $\begin{array}{l}\text { Vulnerable to some pollutants but only when } \\
\text { continuously discharged / leached. }\end{array}$ \\
\hline Low & $\begin{array}{l}\text { Only vulnerable to conservative and mobile } \\
\text { pollutants in long-term when continuously and } \\
\text { widely discharged / leached. }\end{array}$ \\
\hline Negligible & $\begin{array}{l}\text { Confining beds present across which there is no } \\
\text { significant groundwater flow. }\end{array}$ \\
\hline
\end{tabular}

\section{Sample Problem}

A sample aquifer is presented by Figures 3 and 4 . The capture zones that are obtained from WhAEM can be seen in Figures 5, 6 and 7 for 50, 300 and 4000 days, respectively. The final results are presented by Figure 8 .

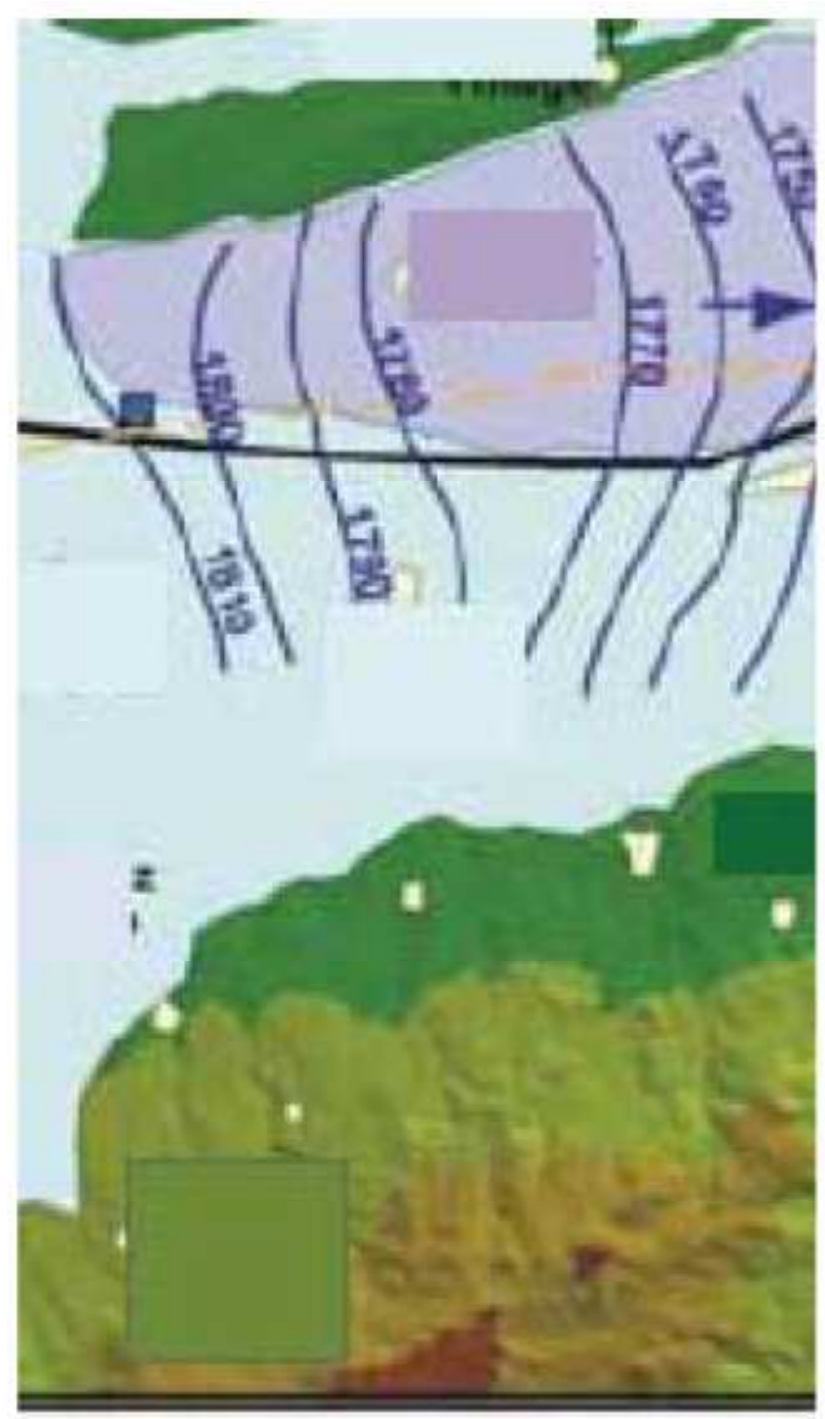

Figure 3. Hydro geologic setting of the sample aquifer. 


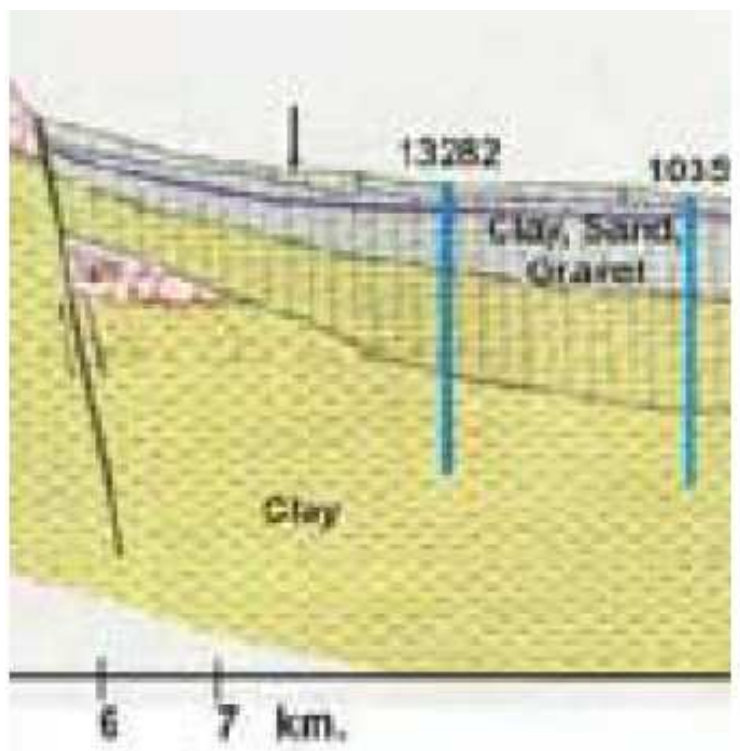

Figure 4. Vertical view of wells of the sample aquifer.

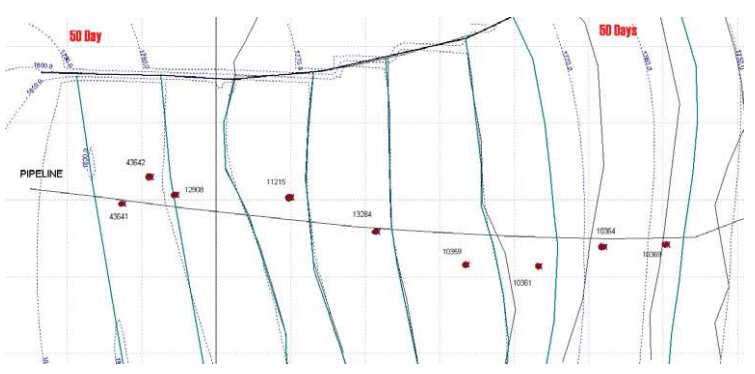

Figure 5. Analysis of 50-Day Wellhead Capture Zone, the aquifer, and the red lines or circles indicate wellhead capture zones.

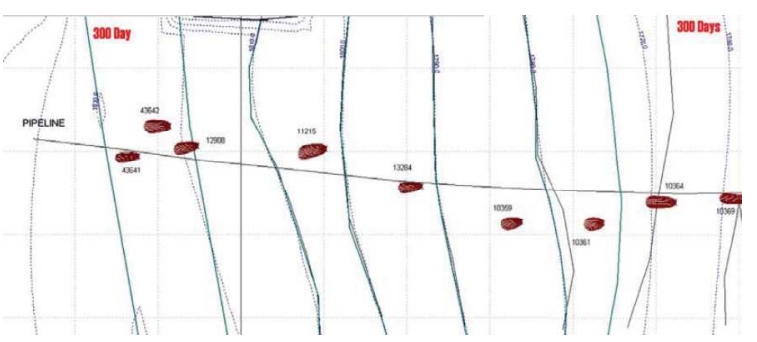

Figure 6. Analysis of 300-Day Wellhead Capture Zone, the aquifer, and the red lines or circles indicate wellhead capture zones.

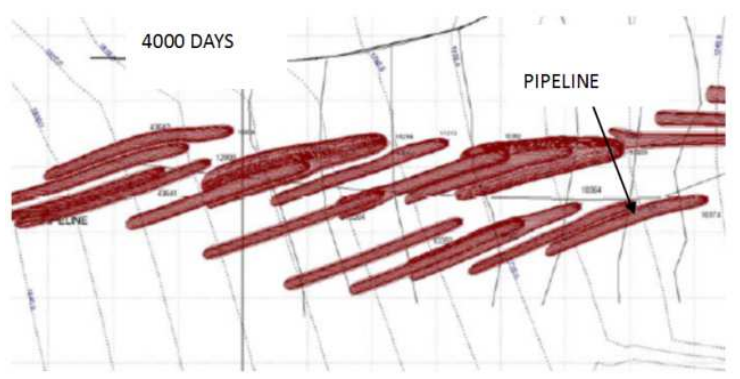

Figure 7. Analysis of 4000-Day Wellhead Capture Zone, the aquifer, and the red lines or circles indicate wellhead capture zones.

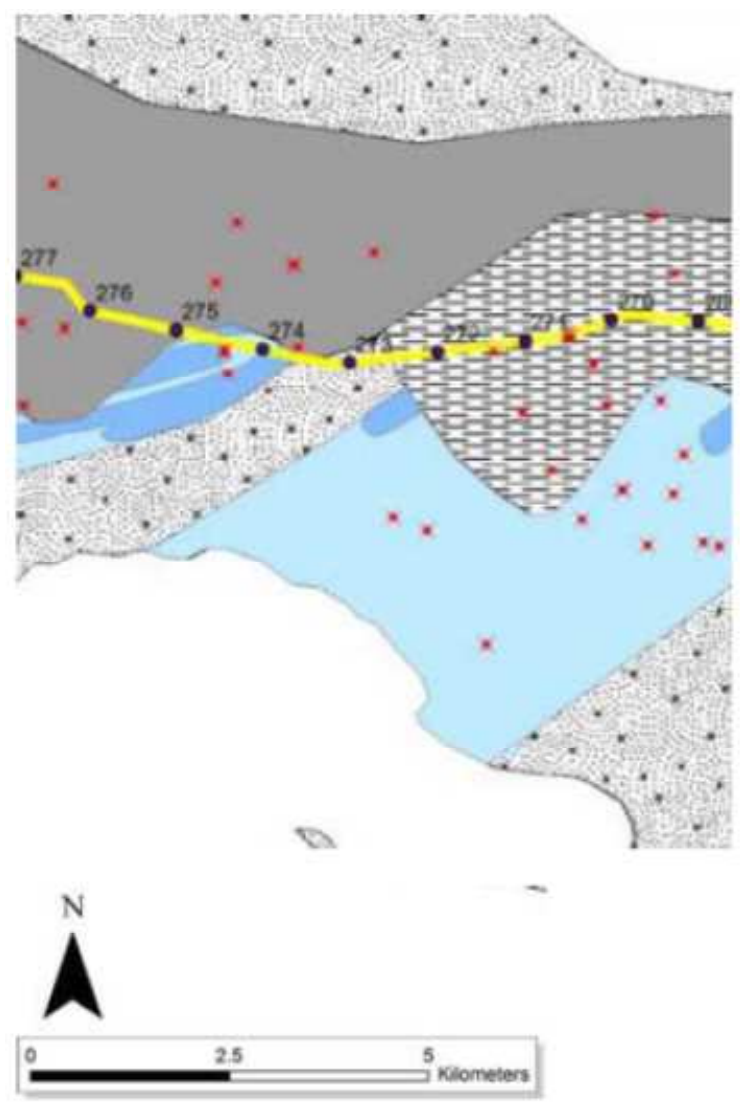

Figure 8. Zone of Contribution (dark and light blue shading) for wells along the pipeline through the sample aquifer.

Table 4. QRA Risk Analysis of the sample aquifer for well sites having a 50-Day and / or 300-Day capture zone intercepting the pipeline.

\begin{tabular}{|c|c|c|c|c|c|}
\hline \multicolumn{2}{|c|}{$\begin{array}{l}\text { Well Site within Capture } \\
\text { Zone (Well Numbers) }\end{array}$} & \multirow[t]{2}{*}{ Contact Potential } & \multirow[t]{2}{*}{ Receptor Value } & \multirow[t]{2}{*}{ Risk Value } & \multirow[t]{2}{*}{ Basis } \\
\hline 50 Day & 300 Day & & & & \\
\hline & 12545 & 0.7 & 0.7 & 0.7 & $\begin{array}{l}\text { Within } 300 \text {-day capture zone in non-artesian unconfined aquifer, } \\
\text { with depth to water level: } 6 \mathrm{~m} \text {; inside regional irrigation area } \\
\text { receptor. }\end{array}$ \\
\hline \multicolumn{2}{|l|}{$\begin{array}{l}12562 \\
54326\end{array}$} & 0.7 & 0.7 & 0.7 & $\begin{array}{l}\text { Within 300-day capture zone in non-artesian unconfined aquifer, } \\
\text { with depth to water level: } 14 \text { / } 19 \text { m; inside regional irrigation area } \\
\text { receptor. }\end{array}$ \\
\hline & 54329 & 0.7 & 0.7 & 0.7 & $\begin{array}{l}\text { Within } 300 \text {-day capture zone in non-artesian unconfined aquifer, } \\
\text { with depth to water level: } 10 \mathrm{~m} \text {; inside regional irrigation area } \\
\text { receptor. }\end{array}$ \\
\hline & 13284 & 0.5 & 0.7 & 0.5 & $\begin{array}{l}\text { Within 300-day capture zone in artesian aquifer; inside regional } \\
\text { irrigation area receptor. }\end{array}$ \\
\hline \multirow{2}{*}{\multicolumn{2}{|c|}{$\begin{array}{l}\text { All Other Areas } \\
\text { (No capture zone } \\
\text { interception with pipeline) }\end{array}$}} & \multirow[b]{2}{*}{0.3 or less } & \multirow[b]{2}{*}{0.7} & 0.3 & \multirow{2}{*}{$\begin{array}{l}\text { Outside of } 300 \text {-day capture zone; if within } 4000 \text {-day capture zone } \\
\mathrm{ZOC}=0.3 \text { (inside recharge area), if outside } \mathrm{ZOC}=0.1 .\end{array}$} \\
\hline & & & & 0.1 & \\
\hline
\end{tabular}




\subsection{Comparing Risk Criteria for the Sample Aquifer Wells}

The two risk assessment criteria are compared using the same data set from the sample aquifer. Table 4 presents the groundwater QRA risk; and risk values are between 0.5 and 0.7 for well sites in the sample aquifer that have a 50-day and / or 300-day capture zone which intercepts the pipeline. The table also indicates low ( 0.3 or less) QRA risk values for other sites outside the 300-day capture zone.

Risk values using the GOD process are shown in Tables 5. Risk values range from moderate $(0.33)$ to negligible $(0.14)$ for the same well sites in the sample aquifer, significantly lower than values obtained using the QRA risk criteria.

Table 5. GOD Risk Analysis of the sample aquifer for well sites having a 300-Day capture zone intercepting the pipeline, [4].

\begin{tabular}{lllll}
\hline Well Numbers & Groundwater Occurrence & Overall Lithology & Depth to Groundwater & Aquifer Pollution Vulnerability \\
\hline 12545 & 0.6 (unconfined covered) & 0.7 (alluvial / fluvial) & $0.8(5-10 \mathrm{~m})$ & 0.33 (Moderate) \\
54326 & 0.6 (unconfined covered) & 0.7 (alluvial / fluvial) & $0.7(10-20 \mathrm{~m})$ & 0.29 (Low) \\
12562 & 0.6 (unconfined covered) & 0.7 (alluvial / fluvial) & $0.7(10-20 \mathrm{~m})$ & 0.29 (Low) \\
54329 & 0.4 (semi-confined) & 0.7 (alluvial / fluvial) & $0.5(10-20 \mathrm{~m})$ & 0.14 (Negligible) \\
13284 & & &
\end{tabular}

Table 6. Crossing the sample aquifer by KPs, including well site, capture zone and Table 3 risk levels.

\begin{tabular}{|c|c|c|c|c|c|}
\hline Risk & High & Moderate & Low & Negligible & $\begin{array}{l}\text { Relation of Crossing to } \\
\text { Recharge Area }\end{array}$ \\
\hline Pipeline KP & 50-Day & 300-Day & 4000-Day & Well & Comment \\
\hline $258.0-262.4$ & & & & None & \\
\hline $262.4-262.8$ & & & & 12539 & Outside of Recharge Area \\
\hline $262.8-265.2$ & & & & None & \\
\hline $265.2-265.8$ & & & & 12540 & Outside of Recharge Area \\
\hline $265.8-266.2$ & & & & None & \\
\hline $266.8-267.1$ & & $266.8-267.1$ & & 12545 & Outside of Recharge Area \\
\hline $267.1-267.4$ & & & & 12545 & \\
\hline $267.4-268.4$ & & & & None & \\
\hline $268.4-268.8$ & & & & 12546 & Outside of Recharge Area \\
\hline $268.8-269.0$ & & & & None & Outside of Recharge Area \\
\hline $269.0-269.4$ & & & & 9714 & \\
\hline $269.4-270.3$ & & & & None & \\
\hline $270.6-270.7$ & & $270.6-270.7$ & & $12982 / 54326$ & Outside of Recharge Area \\
\hline $270.7-271.8$ & & & & $12562 / 54326$ & Outside of Recharge Area \\
\hline $271.8-273.6$ & & & & None & \\
\hline $273.6-273.8$ & & $273.6-273.8$ & & 54329 & Inside Recharge Area \\
\hline $273.8-274.0$ & & & $273.8-274.0$ & 54329 & Inside Recharge Area \\
\hline $274.0-275.5$ & & & & None & \\
\hline $275.5-276.5$ & & & & 125711258812587 & Outside of Recharge Area \\
\hline $276.5-282.1$ & & & & None & \\
\hline $282.1-282.2$ & & $282.1-282.2$ & & 10309 & Inside Recharge Area \\
\hline $282.2-284.4$ & & & & None & \\
\hline $284.4-284.8$ & & & $284.4-284.8$ & 10388 & Inside Recharge Area \\
\hline $284.8-285.1$ & & & & None & \\
\hline $285.1-285.9$ & & & $285.1-285.9$ & $10362 / 10383$ & Inside Recharge Area \\
\hline $285.9-286.0$ & & $285.9-286.0$ & & 13284 & Inside Recharge Area \\
\hline $286.0-286.2$ & & & $288.0-288.2$ & 10382 & Inside Recharge Area \\
\hline $287.1-287.3$ & & & & None & \\
\hline $287.3-288.6$ & & & $287.3-288.6$ & 112415432311215 & Inside Recharge Area \\
\hline $288.6-288.8$ & & & & None & \\
\hline $288.8-289.1$ & & & $288.8-289.1$ & 12908 & Inside Recharge Area \\
\hline $289.1-289.3$ & & & & None & \\
\hline $289.3-289.4$ & & & $289.3-289.4$ & 43641 & Inside Recharge Area \\
\hline $289.4-289.7$ & & & & None & \\
\hline $289.7-290.1$ & & & $269.7-290.1$ & 43642 & Inside Recharge Area \\
\hline $290.1-290.2$ & & & & None & \\
\hline $290.2-290.6$ & & & $290.2-290.6$ & 12909 & Inside Recharge Area \\
\hline
\end{tabular}


this report, the QRA criteria are used to develop the risk profile across the aquifer. Table 6 presents a KP-by-KP crossing of the the sample aquifer and pipeline interception with a capture zone, ZOC, or no interception.

Table 7 contains in values from Tables 4 and 6 of the groundwater risk values for the QRA report.

Table 7. Groundwater Environmental Risk Values for KPs within the sample aquifer.

\begin{tabular}{llll}
\hline $\begin{array}{l}\text { Well Site Capture Zone (Well Numbers) } \\
\text { 50 Day }\end{array}$ & 300 Day & KP Intercept & Risk Values \\
\hline \multirow{2}{*}{$12562 / 54326$} & 12545 & $266-268$ & 0.7 \\
& & $270-271$ & 0.7 \\
& 54329 & 272 & 0.1 \\
& & $273-274$ & 0.7 \\
& 10369 & $275-280$ & 0.1 \\
& & $281-282$ & 0.1 \\
\hline
\end{tabular}

\subsection{Tactics (Specific Response Actions)}

The clean-up decision tree can be seen by Figure 9 .

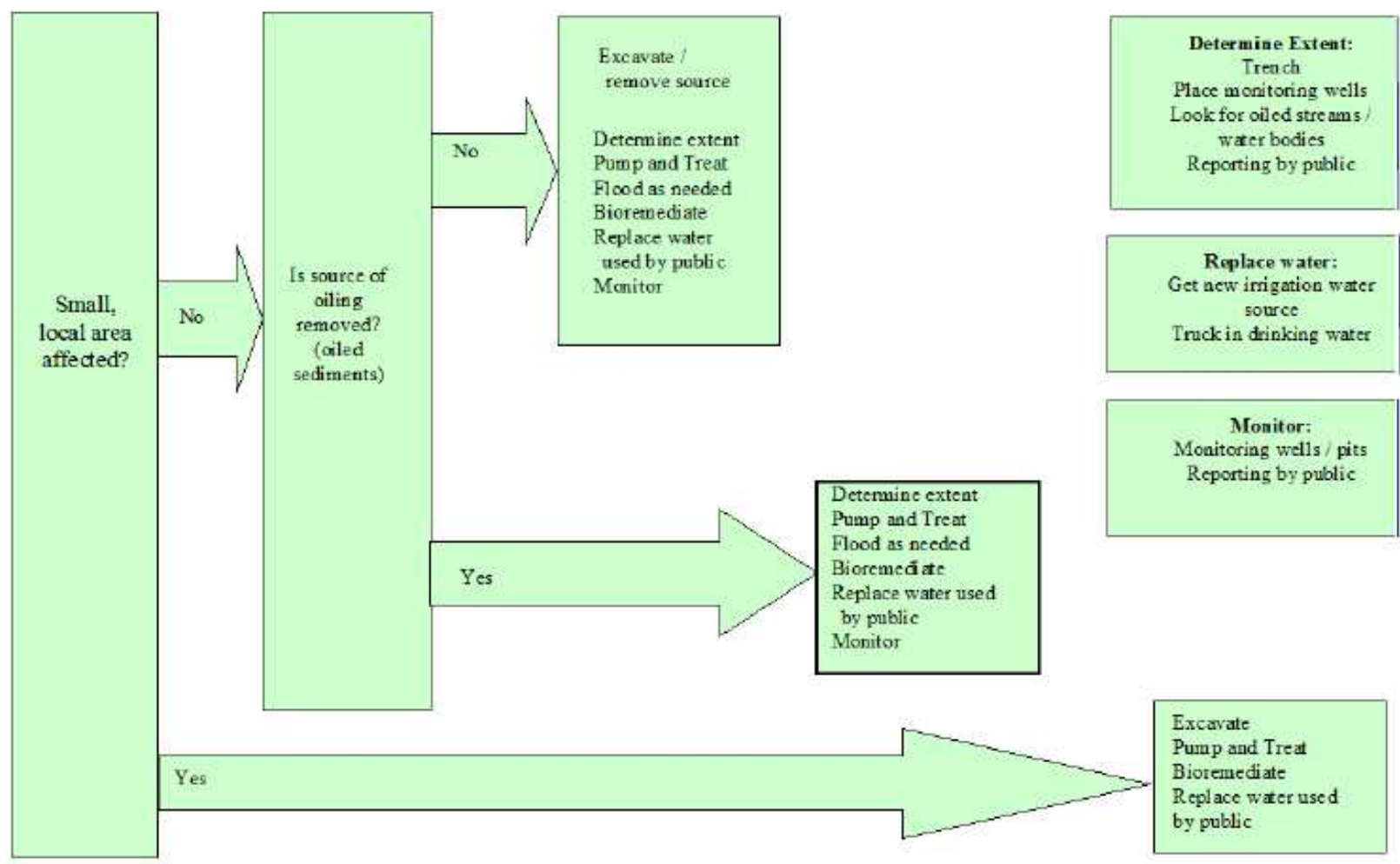

Figure 9. Groundwater cleanup decision guide.

The following tactical actions are designed to meet the strategy of preventing oil from reaching the aquifer, yet provide flexibility depending on the characteristics of the site (e.g. underlying sediment) and of the aquifer (e.g. rate of infiltration, water table level, and depth to filter pipe).

Specific response procedures are as follows:

1. Stop the oil leak and contain spillage.

2. In the sample aquifer, work with the local authorities to cease well pumping if the spill site is within the 50-day capture zone of any well. In other groundwater operational zones, review the area for any new or previously unknown wells within $0.5 \mathrm{~km}$ of the spill site.
In these areas, work with the local authorities to immediately cease any well pumping from the identified wells. The ceasing of local well pumping will inhibit the downward migration of water and oil. Replace water taken from well or otherwise compensate for lost water usage where water well pumping has been halted.

3. Remove oily sediments around and below the pipeline.

4. If contamination is severe, continue to remove contaminated sediments and pump out floating water and oil.

5. If contamination is severe, work with a groundwater expert to review site and sedimentary characteristics. 
Simple percolation tests may serve to indicate rate of potential oil / water infiltration.

6. Where infiltration occurs, and contamination remains, determine the need to drill and pump shallow wells, e.g. 10 to $30 \mathrm{~m}$ depending on groundwater level. The purpose of this new well is to identify and intercept any potential oil transport before it hits the water table.

7. If oil has reached the water table, pump and treat any contaminated water from the top level of the water table. Continue pump and treat water from both shallow and the existing well until contamination is removed.

8. Restart normal operations of the adjacent water wells after confirmation of no contamination.

9. Monitor both the shallow well and existing water well for future contamination.

Identifying Risk and Well Location by KP: Once a spill site is established by KP designator, Table 5 can be used to identify the well site locations, relative risk, and the related capture zone(s) that intercept the pipeline. KPs outside of this table have no capture zone intercepting the pipeline.

Identifying Well and Aquifer Characteristics: As an example, the locations and information of all wells within 500 $\mathrm{m}$ of the pipeline in the sample aquifer must be obtained from the local authorities.

Using Location Maps: Routes to the well site, pipeline intercept areas, and other map related information must be available from the Project's GIS. Specific data sets important to response include:

- Digital 1:25,000-scale topographic maps, available for the entire pipeline route;

- All well site locations and

- All capture zones and ZOCs that intercept the pipeline.

\section{Discussion of Results}

The paper introduces the methodology and analysis of possible groundwater pollution from crude oil pipelines. The analyses are in detail; however necessary softwares, GIS systems and data must be used in a proper way for robust calculations.

Groundwater is very valuable source of water, and cleaning an aquifer is quite expensive, in most case unaffordable. The paper provides an important and useful tool to the planners for avoiding the oil pollution to groundwater due to oil spills from crude oil pipelines

\section{References}

[1] H. M. Cekirge, Pipeline and Groundwater, Maltepe Uni., Int. Rep. 5, Istanbul, 2010.

[2] US EPA, Wellhead Analytical Element Model (WhAEM) 2000, (http://www.epa.gov/athens/software/whaem/), 2000.

[3] S. R. Kraemer, H. M. Haitjema, and V. A. Kelson 2005. Working with WhAEM2000: Capture Zone Delineation for a city Wellfield in a Valley Fill Glacial Outwash Aquifer Supporting Wellhead Protection. EPA/600/R-00/022, updated June 2005.

[4] Groundwater occurrence-Overall lithology-Depth to groundwater (GOD) process, described in World Bank publication: Assessment of Groundwater Pollution Risk, Morris and Foster,

(http://lnweb18.worldbank.org/ESSD/ardext.nsf/18ByDocNa me

/AssessmentofGroundwaterPollutionRisk/\$FILE/Assessmento fGroundwaterPollutionRisk.pdf), 2002.

[5] W. Tong, and Y. Rong, Domenico Spreadsheet Analytical Model Manual, California Regional Water Quality Board, Los Angeles, $\mathrm{CA}$, 16 pp.(http://www.swrcb.ca.gov/ rwqcb4/html/programs/ust/Do menico_steady_state_model_manual.pdf), 1999.

[6] T. E. Reilly and D. W. Pollock, Factors Affecting Areas Contributing Recharge in Shallow Aquifers: U.S. Geological Survey Water-Supply Paper 2412, 21 p., 1993.

[7] J. P. Masterson, K. M. Hess, D.A. Walter, and D. R. LeBlanc, Simulated Changes in the Sources of Ground Water for Public-Supply Wells, Ponds, Streams and Coastal Areas on Western Cape Cod, Massachusetts, U.S. Department of the Interior Water-Resources Investigations Report 02-4143 approx. $10 \mathrm{pp}$. (http://water.usgs.gov/pubs/wri/wri024143/reilly), 2002.

[8] Franklin W. Schwartz and Hubao Zhang, Fundamentals of Ground Water 1st Edition, John Wiley, 2003.

[9] Richard O. Baker, Harvey W. Yarranton and Jerry Jensen, Practical Reservoir Engineering and Characterization 1st Edition, Gulf Professional Publishing, 2015.

[10] An International Conference Analytical Element Modeling of Groundwater Flow, Indianapolis, Intl. Groundwater Modeling Center, April 19-21, 1994

[11] Jacob Bear and H. D. Cheng, Modeling Groundwater Flow and Contaminant Transport (Theory and Applications of Transport in Porous Media) 2010th Edition, Springer, 2010. 